\title{
Identity Contestations in the Turkish Cypriot Community and the Peace Process in Cyprus
}

\author{
By Enver Gülseven*
}

\begin{abstract}
This paper will explore Turkish Cypriot identity in a historical setting and scrutinize the scope of identity contestations within the community in the context of growing affiliation with the European Union. Highlighting the effects of significant issues such as immigration, demographic change, political uncertainty, isolation and economic transformation, it aims to reveal how different notions of identity shapes the preferences of diverse actors in Cyprus by determining available and legitimate policy options in peace negotiations. Particular attention is paid to the post-Annan Plan period and how consecutive failures in negotiations and enduring political limbo leads to new understandings of identity and the emergence of new political parties and movements with alternative preferences concerning the Cyprus Dispute. The paper will conclude that as long as uncertainty continues on the island, the debates over identity and the tension between ethnic and civic understandings of it will remain high and will continue to shape Turkish Cypriot politics.
\end{abstract}

Keywords: Cypriotism, Cyprus Dispute, Identity, Turkish Cypriots, Turkish Nationalism.

\section{Introduction}

The Turkish Cypriot identity is in a process of re-constructing itself following the division of the island in 1974. In this process, two rival understandings of identity, namely an ethnic identity based on Turkish nationalism and a civic identity based on Cypriotism ${ }^{1}$, have been competing with each other. Until recent decades, Turkish nationalism was the dominant conception of identity among the Turkish Cypriots. Nevertheless, its dominance has become increasingly insecure recently, manifested with the rise of alternative identity conceptions. Cypriotist identity became particularly strong after the Europeanization of the Cyprus conflict since 1990s and emerged as the main rival of ethnic nationalism. The election of Mustafa Akınc1, a long-standing advocate of Cypriotist identity and federalism, to the community's leadership in 2015 elections with more than $60 \%$ of the vote was a strong indicator of a shift of identity in Northern Cyprus. Recent surveys also indicate the growing popularity of a more Cypriot-centric Turkish Cypriotness. While only $9.3 \%$ of Turkish Cypriots identify themselves as Cypriot in a 2007 survey $^{2}$ this ration dramatically increased and reached to $43 \%$ in another

\footnotetext{
*Assistant Professor, Girne American University, Cyprus.

${ }^{1}$ Cypriotism refers to idea that Cyprus has its own particular character which are different from the motherland's characteristics (Mavratsas 1998).

${ }^{2}$ See Psaltis (2012).
} 
survey conducted in $2014^{3}$. Furthermore, other surveys reveal that $80 \%$ of the community members support a Cypriot identity, $88 \%$ consider themselves as Cypriot first ${ }^{4}$ and $86 \%$ are willing to accept a bi-zonal, bicommunal federation for resolving the Cyprus issue. ${ }^{5}$

Nevertheless, the rise in Cypriotism in the north does not mean that ethnic nationalism is completely defeated among the Turkish Cypriots. On the contrary, nationalists are making something of a comeback recently, as manifested with the success of Nationalist Union Party (UBP) in 2018 parliamentary elections. Despite emerging as the biggest party in the parliament, the hardliner UBP was ousted from power with the establishment of a four-party coalition government by mainly Cypriotist and anti-status quo parties. The government included the traditional champions of Cypriotism, namely, Republican Turkish Party (CTP) and Social Democratic Party (TDP), as well as moderate nationalist Democratic Party (DP) and the newly-established centre-right Peoples' Party (HP) which openly disapproves the status-quo. These developments reveal the intensification of the struggle between ethnic identity which legitimizes a two-state solution and civic identity which is associated with federalism whereas some political movements and parties are adopting a light version of 'Turkish Cypriotism' in search of a middle ground.

Identity contestations have a significant impact on the legitimacy of Turkish Cypriot leadership as well as its relationship with Ankara and thereby on the preferences of the Turkish side ${ }^{6}$ in Cyprus peace talks. Contested Turkish Cypriot identity has been the subject of increasing scholarly attention especially since mid2000s. Previous studies generally focused on the social and political transformation in the north which enabled alternative identities to challenge Turkish nationalism, (Lacher and Kaymak 2005) and explained identity fluctuations as a response to variations in socialization (Vural and Rüstemli 2006) and in the context of Turkish Cypriots' transnational position between Turkey, Greek Cypriots and the EU (Ramm 2006). Nonetheless, the impact of a contested identity on the peace process and relations with Turkey has been largely overlooked in the current literature. This paper is a part of this growing academic interest that aims to explaining how identity contestations in the north influence the preferences and position of the Turkish side in Cyprus peace negotiations. It also aims to provide an update for literature on Turkish Cypriot identity by focusing on the effects of more recent developments. Apparently, identities are not the only factors shaping the preferences of the Turkish side in peace talks, yet they determine available options which can be legitimized in the eyes of public opinion. The study has been shaped by data collection, which includes election results, polls and surveys, media sources and literature on Turkish Cypriot identity.

\footnotetext{
${ }^{3}$ SCORE (2014) Predicting peace: The social cohesion and reconciliation index as a tool for confl ict transformation. Nicosia: UNDP-ACT.

${ }^{4} 2015$ Survey by Insights Market Research, University of Nicosia published in Andreou,E. 2015 "Favouring a Cypriot Identity but Differing on What it Means", Cyprus Mail, 25 February.

${ }^{5} 2017$ Survey University of Cyprus Centre for Field Studies cited in Friends of Cyprus, Issue 61.

${ }^{6}$ Turkish side refers to the Republic of Turkey and the de-facto Turkish Republic of Northern Cyprus recognized only by Ankara.
} 
Before analysing contested nature of Turkish Cypriotness, let us first briefly discuss the importance of identity in the formulation of preferences and threat perceptions. The concept of identity is central to the constructivist approach in International Relations theory. According to constructivists, identities are necessary in both domestic and international politics. As Hopf (1998: 175) says 'they perform three necessary functions in a society: they tell you and others who you are and they tell you who others are'. By doing so, identities suggest a particular set of interests for actors. Even though actors may choose particular identities in accordance with their interests, these interests themselves presuppose still deeper identities. The constructivist account of identity also sheds light on the relationship between identity, power and threat perceptions. According to constructivists such as Risse Kappen (1996: 367) power translates into threat within a certain set of understandings and representations.

Although identities are helpful in explaining the formation of interests and threat perceptions, they are not stable and are often contested between different social groups in a society (Barnett 1996: 400-432). To put it differently, no state's identity is totally secure or stable since identities are always open to contestation. Nonetheless, the identities of some states at certain times may be less secure than others. The scope of identity contestation will depend on many factors such as homogeneity of a society in terms of ethnicity, race or religion, the economic conditions, the political system and international status as well as affiliation to other national or international political entities. In unrecognized states which lack external sovereignty like Northern Cyprus, a secure identity plays a vital role in state consolidation and the maintenance of internal sovereignty (Rodger 2015). Such entities, which are generally established through use of force in a homogenized territory, can draw upon the memory of civil war while fostering the image of a 'common external enemy' to achieve national unification and consolidate their statehood (Kolsto 2006). Nevertheless, shifting perceptions of belonging can severely undermine the legitimacy of unrecognized states while reshaping the preferences of political actors in peace negotiations and eventually may lead to their voluntary abandonment of claimed statehood. In accordance with this theoretical framework, let us now focus on identity construction among the Turkish Cypriots in a historical setting and the rising identity contestations within the community in recent decades. Subsequently, the discussion will shift to the effects of important turning points such as the failure of the Annan Plan ${ }^{7}$ and how consecutive failures in negotiations leads to new understandings of identity and the emergence of new political parties with alternative preferences for a solution to the Cyprus issue.

\footnotetext{
${ }^{7}$ A United Nations proposal, named after Kofi Annan, for resolving the Cyprus Problem and establishing a federal arrangement on the island. The plan was revised a number of times before being put to simulatenous referenda in 2004.
} 


\section{Construction of Turkish Cypriot Identity}

Turks firstly started to settle in Cyprus following the Ottoman conquest of the island in 1571. During the Ottoman period, they shared the Millet System with the island's indigenous Greek-speaking Orthodox community under which religion became the crucial visible component of their separate identities (Vural and Rüstemli 2006). Accordingly, the island's two communities were institutionalized as distinct cemaats (political/religious community) and were able to choose their own judicial and administrative officials. As Yilmaz (2005: 76) stated, the Millet System encouraged the existing tendency towards separation and exclusive political socialization and thus thwarted the construction of a collective Cypriot identity. The beginning of Greek War of Independence against the Ottoman Empire in 1821 accelerated the spread of Greek nationalism among the Cyprus' Greek community through the guidance of the Orthodox Church. Following the Greek independence in 1832, these sentiments in the community were translated into the idea of uniting Cyprus with 'motherland' Greece, known as enosis.

The replacement of Ottoman rule with British in 1878 further encouraged Greek Cypriot demands for enosis while Turkish Cypriots lost their Ottoman legal privileges and feared a possible Greek domination on the island (Y1lmaz 2005: 77). For most of the British period (1878-1960), religion remained as the most important aspect of identity for both communities. As Pollis (1973: 591) stated British colonial policies strengthened identification within each community and sharpened their cleavages. The Turkish Cypriot community continued to identify itself as Ottoman or Muslim before the emergence of nationalism in Turkey. Due to lack of ethnic consciousness, most of Turkish Cypriots preferred the continuation of the British rule on the island and did not develop an alternative to enosis.

The First World War (WWI) and the subsequent Turkish War of Independence can be regarded as a turning point in the development of Turkish nationalism in Cyprus. Following the WWI, the axis powers occupied several parts of the Ottoman Empire and the British annexed the island of Cyprus. However, the success of the War of Independence led by Kemal Atatiurk and the establishment of the new Republic of Turkey enhanced national consciousness among many Turkish Cypriots. Although they were excluded from the nationbuilding project in Turkey, many adopted the Kemalist ideology of Turkish nationalism which highlighted secularism and equated modernization with Westernization. Turkish Cypriot elites did not only perceive Kemalism as an appropriate instrument for modernizing their community but also as a tool for resisting Greek nationalism on the island. Consequently, most Turkish Cypriots adopted Kemalist values voluntarily and earlier than many Turkish mainlanders (Bryant 2004: 233). This voluntary and swift adoption was also facilitated with the familiarity of most Turkish Cypriots with Western lifestyle and culture due to the experience of British colonial rule. It was also a reflection of a stronger resistance against enosis demands which took a violent stance after the end of the Second World War (WW2). 
When it became clear that the British will eventually leave the island in the process of de-colonization, Turkish Cypriot nationalists started to promote the idea of taksim, the partition of Cyprus between Turkey and Greece. Mid-1950s witnessed the peak of Turkish nationalism and the idea of taksim among Turkish Cypriots. The community's leadership initiated some campaigns such as 'From Turk to Turk' aiming to promote trade relations within Turkish Cypriots while discouraging trade with Greek Cypriots. Simultaneously, most of the original Greek names of the island's Turkish settlements were Turkified. In brief, the national consciousness of Turkish Cypriots grew in direct proportion to the rise of enosis and acted as the main justification for the preference of taksim. (Markides 1977: 23)

Since the tension over the future of Cyprus brought the possibility of a war which threatened to involve the United Kingdom, Turkey and Greece, the concerned parties began seeking alternatives to enosis and taksim. Eventually, the creation of an independent and consociational Republic of Cyprus (RoC) was agreed in 1960 by the British, Turkish and Greek governments. However, as Markides stated (1977: 25) 'there was no festivals, no ringing of church bells, no parades, no dancing people in the streets of Cyprus celebrating independence'. On the contrary, some Turkish Cypriots waiving Turkish flags headed to Famagusta port to celebrate and welcome the arrival of 650 Turkish soldiers as part of the Treaty of Guarantee. On the other hand, many Greek Cypriots claimed that Turkish Cypriots were given a disproportionate influence and regarded the constitution as illegitimate and discriminatory.

Unsurprisingly, the republic's bi-communal system collapsed in 1963 after the Turkish Cypriot rejection of some constitutional amendments proposed by the Greek Cypriot President. The constitutional crisis also triggered the beginning of inter-communal violence and the physical separation of the island's two communities. Due to security concerns, many Turkish and Greek Cypriots left their properties in mixed villages and neighbourhoods and re- settled in areas where their community members constitute the majority. Nicosia was also divided by the UN into its Turkish and Greek sectors. Furthermore, Turkish Cypriots withdrew their representation from the institutions of the Republic which became entirely dominated by Greek Cypriots. ${ }^{8}$

As Ramm (2006: 525) stated, three years of common administration under the umbrella of the bi-communal republic was too short to permit a nation-building process on the island. Indeed, the political elites did not have any intention of promoting a common identity between Turkish and Greek Cypriots. Right after the RoC's establishment, its first President Makarios, is reported to have said 'the agreements have created a state but not a nation' (Stephen 1997: 2). Indeed, the lack of a collective identity prepared a suitable ground for constitutional crisis and inter-communal violence. Moreover, geographical separation and limited social interactions after 1963 decreased the chances of inter-communal identification and the formation of a single Cypriot identity. In contrast, the beginning of physical split further enhanced two distinct and antagonistic identities triggering a civil war

${ }^{8}$ Whether Turkish Cypriot withdrawal was voluntary or whether they were forced out by the Greek Cypriots is still a major source of debate between the two sides. 
and the events of 1974 when the Turkish army intervened in the wake of a Greek military coup. This intervention resulted in the partition of the island and the establishment of two separate administrations in homogenized territories. In 1975, the exchange of population was agreed in Vienna between the two sides of the conflict and Turkish and Greek Cypriots were transferred to the north and the south of the island respectively. A homogenized territory guarded by the Turkish army allowed a state-building process in the north accompanied by the consolidation of ethnic identity and a preference for two-state solution although Turkish Cypriot leadership unwillingly continued to negotiate for a federal agreement. As Kolsto (2006: 737) stated, 'in peace talks between unrecognized states and their parents a federal solution is accepted by both parties in principle, yet one or both generally pretend to accept such an arrangement'.

The events of 1974 deeply influenced the identity perceptions of the island's communities. The physical division did not only halt the interaction between the Turkish and Greek Cypriots but also ended the visibility of the 'other'. However, the effects of the division were felt differently in the south and the north of the green line. ${ }^{9}$ In the south, military defeat revealed dangers of extreme nationalism and enhanced Cypriotism as an alternative ideology. In contrast, Turkish nationalism was strengthened by the euphoria of the military victory in the north. The establishment of the Turkish Republic of Northern Cyprus (TRNC) in 1983 by Rauf Denktaş, although recognized only by Ankara, enhanced the institutionalization of ethnic nationalism among Turkish Cypriots. The unrecognized state's nationalist ideology portrayed 'motherland' Turkey as the liberator of Northern Cyprus which was designated as yavruvatan (babyland). Likewise, Turkish Cypriots were depicted as an indivisible part of greater Turkish nation. Accordingly, Cypriotness was only a geographical definition and did not form a basis for a common Cypriot national identity.

Although Cypriotness was defined only as a geographical feature, Turkish nationalism aimed to fix Northern Cyprus as a 'home' for Turkish Cypriots. As Özkırımlı and Sofos (2008: 103) stated 'nationalism is almost invariably haunted by a fixation on territory, the quest for a "home", actual or imagined'. Nevertheless, this reconstruction has been an uneasy task for the Turkish Cypriot leadership. Firstly, the borders of the TRNC were not corresponding with the conventional perceptions of ethnic, linguistic and religious boundaries on the island. In order to tackle this problem, the Turkish Cypriot leadership immediately changed the Greek names of all settlements in the north. The landscape was also turkified with the construction of new mosques and the paintings of Turkish flags and symbols on the mountains. Another important aspect of the construction of a Turkish 'home' in the north was encouraging migration from Turkey. The Turkish migrants were granted abandoned Greek Cypriot properties as well as Turkish Cypriot citizenship almost upon arrival. Most of those who arrived during 1970s and 1980s were farmers from various parts of Turkey and were mostly settled in isolated areas such as the Karpaz peninsula which was considered less desirable by Turkish Cypriots (Hatay 2005: 12). Subsequently, Turkish Cypriots who used to

${ }^{9}$ Green Line refers to the UN controlled demilitarized buffer zone between the nortehrn and the southern parts of the island. 
live in a multi-cultural environment together with Greek Cypriots founded themselves in an ethnically homogeneous territory together with Turkish migrants. Gradually this new environment prepared a suitable ground for the rise of an alternative identity to ethnic nationalism by providing an 'internal other' to the indigenous Turkish Cypriots while justifying and empowering federalist preferences.

\section{Rise of an Alternative Identity to Turkish Nationalism: Cypriotism in Northern Cyprus}

During the 1980s, Cypriotism has emerged as an alternative identity to Turkish nationalism among some Turkish Cypriots. Cypriotist discourse was originated from the Marxist ideology and depicted ethnic nationalism as a case of false consciousness serving the interests of the bourgeoisie in both sides. Accordingly, it highlights the differences of Cyprus from both Greece and Turkey while stressing and promoting a common Cypriot culture and identity. This ideology was particularly popular among younger Turkish Cypriots who embraced leftist ideology while studying at Turkish universities during late $1970 \mathrm{~s}^{10}$ and believed that the 'internationalist' tradition of the left could facilitate the peaceful co-existence of Turkish and Greek Cypriots in a re-united Cyprus (Vural and Rüstemli 2006: 339). Cypriotists supported a civic identity which would allow diversity, while preserving a sense of geographical location and this is associated with the preference of a united and federal Cyprus. Accordingly, the consciousness of 'mother Cyprus' as opposed to Turkey as 'motherland' was proposed by the Cypriotist circles in the north.

Nevertheless, this camp which included the leftist political parties, most trade unions, teacher's organizations, and some civil society organizations remained as a minority and Turkish nationalism upheld its dominance in the north until late 1990s. Nevertheless, the end of Cold War triggered the rise of identity politics in the world and Northern Cyprus was also influenced by this global trend. Turkish Cypriot leftist political parties abandoned their pro-Soviet stance and adopted a Western European style social-democratic identity. Indeed, they emerged as the strongest supporters of Cyprus' EU membership and perceived it as the only possible framework within which a common Cypriotness can be constructed (Ramm 2006: 531).

While the leftist parties quickly and eagerly welcomed the involvement of the EU in the Cyprus Dispute, the parties on the right perceived it as a threat and promoted even closer ties with Turkey. In 1991, the TRNC government led by UBP's Derviş Eroğlu abolished the passport requirement for Turkish citizens when entering the country. Indeed, this was one of the factors which caused a dramatic increase in the number of Turkish migrants in Northern Cyprus. Rising

\footnotetext{
${ }^{10}$ During late 1970 s, educational system was highly politicized in Turkey and a deep polarization emerged between extreme right and left groups in the country. Turkish universities particularly became the loci of ideological violent clashes among various political groups supporting conflicting political, economic, and religious ideas.
} 
interaction between Turkish Cypriots and the migrants had made differences more noticeable, mainly concerning the latter's conservative lifestyle and lower socioeconomic status (Lisaniler and Rodriguez 2002: 184). Indeed, the government's attempt to encourage migration was also economically motivated due to the transformation of Turkish Cypriot economy following the imposition of EU's economic sanctions in 1994. In order to reduce the negative effects of trade restrictions, the TRNC authorities implemented an economic re-structuring based on neo-liberal privatization, promotion of small business enterprises and the growth of tourism industry. Consequently, the Turkish Cypriot economy grew during 1990s despite the restrictions and the Turkish migrants were seen as the source of urgently needed cheap labour. Nonetheless, the unintended consequence of these developments was the polarization of the north's population into two main groups namely Turkish Cypriots and Turkish migrants. Despite their lower economic status, migrants especially those who are naturalized citizens of the TRNC, were seen as a threat to Turkish Cypriot identity and political will by Cypriotists.

Apart from a class-based distinction, cultural and ethnic differences between the Turkish Cypriots and the new migrants also increased hostility between the two groups. Many of the new-comers were of Kurdish or Arab descent from the impoverished South-eastern Anatolia and settled in old Nicosia, which increased their visibility. The socio-economic inequality also dramatically increased crime rates in the north creating a perceived or actual relationship between crime and Turkish migrants. Indeed, non-stop immigration from Turkey and rising crime rates greatly contributed to the defeat of UBP in 1993 elections which brought a coalition of CTP-DP. The new government immediately took measures to lower migration and limited citizenship rights to persons who lived in Cyprus for at least five years. Meanwhile Cypriotist ideas continued to grow particularly among younger generations who felt increasingly alienated from their unrecognized state and the nationalist approach of the right which appeared as self-isolationist and old-fashioned. (Hatay 2008: 162)

The intensification of RoC's institutional links with the EU and economic downturn in the north in the second half of 1990s, further intensified identity debates among Turkish Cypriots. On one hand, many expected that the EU membership process will facilitate the solution of the Cyprus Dispute and all economic ills of the north. On the other hand, the emergence of Cyprus' EU membership as a solid possibility enhanced the attractiveness of Cypriot identity which is understood as part of a greater European identity. As Ramm (2006: 524) put it 'Turkish Cypriots have entered into a new process in which a new identity is constructed in connection with their trans-national position between Greek Cypriots, Turkey, the Turkish migrants and the EU'. Turkish Cypriot civil society organizations activated interaction with European institutions and entered into a process of social learning and Europeanization. Hence, supra-national European identity acted as a model for the consolidation of civic Cypriot identity while European norms provided a normative framework for the struggle against ethnic nationalism. This process also transformed dominant attitudes among many Turkish Cypriots, especially regarding how they define their own identity and an 
ideal solution to the Cyprus Dispute. Moreover, it constructed an attachment for the EU when combined with the political, economic and identity insecurity of the community due to its decades-old isolation.

Despite these sentiments, the nationalist leadership in the TRNC called for closer integration with Turkey as a response to the beginning of RoC's accession talks with the EU and the Union's exclusion of Ankara's candidacy in 1997. Denktaş also declared that he would negotiate for a confederal solution only after the recognition of the TRNC which revealed growing divergence between Turkish Cypriot masses and elites. However, the political climate started changing after the approval of Turkey's EU candidacy in 1999 which forced Turkish Cypriot leader to abandon its insistence on recognition and confederalism. Some other factors also restored interest for the re-unification of the island which included the beginning of Greek-Turkish rapprochement following the so-called 'seismic diplomacy' ${ }^{11}$, growing economic concerns in the north and a legitimacy crisis. The banking crisis in 2000 which has resulted in the liquidation of ten banks and the following Turkish financial crisis of 2001 were particularly destructive for the unrecognized states' internal legitimacy. Consequently, a growing number of north's population began questioning the competence of the TRNC to represent Turkish Cypriots' political will (Lacher \& Kaymak 2006). In this context, Denktaş initiated another round of negotiations in 2002 with his Greek Cypriot counterpart Glafcos Klerides with the aim of finding a solution before the island's EU entry. Meanwhile, Turkey's new Justice and Development Party (AKP) with its antiestablishment tradition and roots in political Islam came to power in the general elections of 2002. The new Turkish government signalled a radical change in foreign policy, adopted a pro-EU approach ${ }^{12}$ and prioritized transforming Ankara's Cyprus policy (Kınacıoğlu and Oktay 2006) even if this would require overcoming hardliner Denktaş who was a traditional ally of the secularist Turkish parties as well as the army. The AKP leader Erdoğan immediately started a public fight with Denktaş, blamed him for the lack of solution and began cooperating with Cypriotist parties. In brief, the EU process weakened dominant secularist/ ethnic identities in both Turkey and the north while empowering suppressed identities and enabling their cooperation.

Despite growing pressure from the Turkish government, Denktaş maintained his hard-line position and the negotiations soon became deadlocked. To revive the talks, the UN's Secretary-General Kofi Annan visited the island and submitted the two sides a blueprint agreement. The negotiation process was a turning point for the Cypriotist camp in the north and solution was portrayed as a way to defeat Turkish nationalism, secure the Cypriot identity and extend its 'self' to the European identity. Accordingly, Cypriotist leaders highlighted the unified fate of all Cypriots and emphasized the commonalities between the two Cypriot

\footnotetext{
${ }^{11} \mathrm{~A}$ diplomatic initiative following successive earthquakes in Turkey and Greece and an improvement in their bilateral relations.

${ }^{12}$ The transformation of political Islam is still a major debate among political scientists. While some argued that this change was merely for tactical reasons with the aim of reducing the army's influence in Turkish politics, others explained the transformation with a social learning process following the latest intervention of the army in 1997. For a detailed discussion see Dağ1 (2005).
} 
communities. The term 'Turkish-speaking Cypriot' was also presented as an alternative identification to the more common term of 'Turkish Cypriot'. Some Cypriotists also promoted the usage of Turkish Cypriot dialect rather than standard Turkish as a marker of a separate identity and a symbol of resistance to Ankara's socio-political influence in the north.

During the negotiations, some leftist activists criticized Turkey and its military forces on the island openly to the extent of calling Ankara a colonial, occupying power. Cypriotist discourses demonized the status quo and particularly highlighted the demographic threat posed by immigration and a fear of the potential extinction of Turkish Cypriots. Such discourses also included xenophobic and discriminatory elements against the Turkish migrants which were justified with linking migration from Turkey with allegations of a political colonization by Ankara (Hatay 2008). In this context, four massive demonstrations were organized between late 2002 and early 2003 to call for the resignation of Denktaş and an immediate solution to the Cyprus Dispute. The period witnessed the greatest domestic challenge to the legitimacy of the TRNC since its establishment in 1983.

This political climate eventually triggered the surprising opening of some checkpoints at the green line on 23 April 2003 which brought a limited freedom of movement between the north and the south. Subsequently, all Cypriots gained the chance to cross from one side of the island to the other which allowed them to interact freely and construct their own images irrespective of the official discourses. Access to south, which experienced a steady economic growth since 1974, provided Turkish Cypriots with a re-confirmed image of Cyprus' principal 'European' character. Many were particularly impressed with the cosmopolitan environment of the south as well as the availability of an abundant range of consumer goods carrying global brands and began highlighting the Cypriot or selfaffirmed Western aspect of their identity. This climate unsurprisingly brought the victory of the Cypriotist CTP in 2003 parliamentary elections, bringing the party's leader Mehmet Ali Talat to premiership.

Re-unification rallies and the election results were portrayed by the Turkish and international media as a sign of the erosion of Turkish nationalism in Cyprus. Turkish sources particularly highlighted the abundance of European and proposed Cypriot flags during the demonstrations. ${ }^{13}$ The Turkish media coverage of the prounification rallies, election results and rising anti-Turkish activism in the north gradually undermined the traditional perception of the Cyprus problem as a 'national cause' in Turkey and weakened the public sensitivity on the issue. This gave the AKP government an opportunity to push for new negotiations which firstly began in Cyprus and later moved to the city of Bürgenstock in Switzerland. Although, Mr. Denktaş rejected to participate, Mr. Talat and the leader of his coalition partner Serdar Denktaş represented the Turkish side in the talks.

\footnotetext{
${ }^{13}$ Star Newspaper 16 December 2003. In the nationalist discourse anavatan (motherland) refers to Turkey whike yavruvatan (babyland) is used for Northern Cyprus. However, the headline of Star newspaper intentionally used Yav-rum which might have a meaning like half-Greek in Turkish.
} 
Eventually, the UN submitted the final version of the so-called Annan plan which suggested the establishment of the United Cyprus Republic under a federal system. The two parties conceded to run simultaneous referenda on the plan in both sides. As the date of referenda approached, the Cypriotist discourses became increasingly popular while reaction to Turkish nationalism reached its peak. Nationalist rhetoric 'How happy to say I am a Turk' was changed into 'How happy to say I am a Cypriot' (Hamit 2009). Despite the opposition of Denktaş, the Turkish government and Cypriotist parties in the north promoted a strong 'yes' vote whereas the Greek Cypriot leadership and most political parties encouraged Greek Cypriots to reject the plan. The rejectionist camp in the south even included the Progressive Party of Working People (AKEL) which was seen as the strongest advocate of Cypriotism. Ultimately, most Greek Cypriots $(75 \%)$ rejected the Annan Plan while Turkish Cypriots overwhelmingly accepted it with $64 \%$. Despite the failure and enduring division, Greek Cypriots entered the EU on 1 May 2004 representing the entire island and the European acquis is suspended in the north until a comprehensive solution.

\section{Cypriotism in the Post-Annan Plan Period}

Although bitterly disappointed with the Greek Cypriot rejection, most Turkish Cypriots celebrated the 'yes' vote due to expectations regarding the end of their isolation. The EU's efforts to ease the isolation of Turkish Cypriots remained limited to financial assistance, trade across the green line and some high-level meetings with Turkish Cypriot leaders, yet Cypriotism sustained its popularity in the north and brought the victory of Talat in 2005 presidential elections. Enduring support for leftist parties stemmed from hopes concerning greater engagement with the world if not recognition and an economic boom in the immediate aftermath of the Annan Plan through the penetration of global and Turkish capital. Through controlling both government and the presidency, CTP monopolized interaction with the EU and emphasized the importance of compliance with European norms (Kyris 2012). Nevertheless, Cypriotism was transformed into an opposition against Ankara's certain policies on Cyprus and unilateral Europeanization rather than an emphasis on solution and bi-communality.

Despite Cypriotism's transformation in the north, 2008 witnessed a revival in unification talks following the victory of AKEL's Dimitris Christofias in Greek Cypriot presidential elections. Christofias' Presidency had finally brought two Cypriotist leaders to power in both sides of the green line and was regarded in the north as an attempt by Greek Cypriots to correct their 'mistake' in 2004 (Loizides 2015). Soon, an indirect negotiation process was re-launched through technical committees. Considering the disappointment with the AKEL's position in 2004 referendum, Talat was more cautious during the talks. However, most of his supporters were still optimistic that Cyprus Dispute could be solved shortly considering AKEL's long tradition of bi-communal engagement with Turkish Cypriots. During the indirect talks, the two leaders agreed to open a new pedestrian crossing on the capital's main shopping thoroughfare, Ledra/Lokmacl 
Street, which was once symbolizing the island's division while agreeing on the concepts of single citizenship and single sovereignty. Aside from these issues, the two leaders' have remained far apart on even how to recommence formal negotiations. Later developments such as the Greek Cypriot oil exploration in the Mediterranean Sea and the decision of the European and British courts about the Greek Cypriot properties in the north, the Oram's case, ${ }^{14}$ caused tension during the negotiation process.

Meanwhile, the disillusionment among Turkish Cypriots over the lack of progress in the talks, internal governance problems and stagnating economic conditions, undermined the popularity of CTP. The first blow would come in 2009 general elections in which the UBP won the largest percentage of the vote with a light Cypriotist slogan of 'I am Cypriot, I am Turk, I am democrat, I am UBP' (Hamit 2009). One year later, the nationalist parties established an alliance and unified their forces against Talat in the presidential elections for the first time since 1990s. Furthermore, conditions in Turkey did not enable the AKP government to support Talat and Cypriotist parties unlike the Annan plan period. According to Ankara, intervention was not only hard but also worthless considering the Greek Cypriot alleged inflexibility in the negotiations (Loizides 2015: 87). Talat was eventually defeated by UBP's candidate Derviş Eroğlu who became the third President of the TRNC.

Despite nationalist comeback in elections, Cypriotists endured their resistance against Ankara's policies on the island. Indeed, the signing of an economic protocol with Turkey to re-structure north's economy caused great resentment among Turkish Cypriots and was utilized by the opposition. The resistance was not merely against proposed austerity measures and the flow of Turkey's 'green capital ${ }^{15}$ but also against Ankara's attempts to enhance the role of religion in the north. Measures taken in the above context included the construction of several mosques, legalizing Quran courses, the opening of a Theological School, and the establishment of the Faculty of Theology. Such developments were perceived by many as a threat to Turkish Cypriot's secular identity and lifestyle. Public upheaval soon became manifest with a series of rallies in 2011 with the participation of thousands of Turkish Cypriots who held banners calling for peace while waiving European and Cypriot flags. As a response to growing public discontent and revival of Cypriotist movements, Eroğlu declared his consent for a federal solution, shifting from his earlier stance. Moreover, the discovery of gas in the Eastern Mediterranean Sea increased pressure for a solution on the Greek side as well who began feeling the destructive effects of the Euro crisis. Since solution could speed up economic recovery by easing the transfer of natural resources to outside markets, the appeal of reunification was boosted in both sides of the island.

\footnotetext{
${ }^{14}$ The courts decided that although Greek Cypriots does not have effective control in Northern Cyprus, the decisions of the courts in the South regarding Greek Cypriot properties in the North are applicable through EU law. The decision came a big blow to Turkish Cypriot economy especially to the construction sector and tourism.

${ }^{15}$ The Green capital refers to the capital resources owned by the religiously conservative bourgeoisie in Turkey.
} 
The economic crisis in the south also led to the defeat of Christofias in Presidential elections by Nikos Anastasiadis who had supported the Annan Plan back in 2004.

In his victory speech, Mr. Anastasiadis said 'I sincerely wish to find a solution to the Cyprus Problem so that both sides can live together in Europe ${ }^{16}$. After the elections, the negotiations were expected to commence on October 2013. Nonetheless, the Greek side insisted on a joint declaration before the beginning of official negotiations. The declaration was achieved in February 2014 and highlighted the unsustainability of the status quo, set the framework for the new negotiation process and confirmed the main principles for a settlement. The adoption of the Joint Declaration was followed by formal negotiations with a new momentum for the settlement of the Cyprus Dispute. Nevertheless, the talks were suspended when Turkey sent a warship to the Eastern Mediterranean Sea to monitor Greek Cypriots unilateral exploration of natural gas reserves off the island's coast. Mr. Anastasiades rejected to attend the meeting on 9 October 2014 and the talks were only resumed following the triumph of Cypriotist leader Mustafa Akıncı in the north's 2015 Presidential elections.

The elections between two polarizing candidates, incumbent Eroğlu and Akıncı, reflected a conflict of identities comprised by Turkish nationalism versus Cypriotism. Akıncı refered to Turkey and the north as two 'sibling countries', while rejecting the conventional 'motherland- babyland' rhetoric and emphasized the importance of Turkish Cypriots' self-sufficiency, change and solution in his campaign $^{17}$. Whereas, Eroğlu's campaign emphasized maintaining Turkey's guarantee in Cyprus and promised a solution within two years ${ }^{18}$. Another candidate was Kudret Özersay, a former negotiator and academic, who highlighted domestic issues and promised to combat corruption and nepotism while following an active diplomacy in negotiations ${ }^{19}$. The triumph of Akınci can be explained by his ability to gather the support of the pro-solutionist Turkish Cypriot electorate who wanted to secure their Cypriotist identity through a solution and the EU membership.

Consequently, the election results gave the negotiations a new breath of fresh air as Anastasides returned to the table, beginning a new round of talks. Soon, the two leaders agreed working on confidence building measures. Akıncı announced the abolition of visa slip requirement for Greek Cypriots when visiting the north, while Anastasiades submitted the locations of minefields in the region that had been planted by Greek Cypriots during the conflict. Subsequently, the two sides achieved a certain level of convergence on governance and citizenship yet disagreed on territory and security issues. During late 2016 and 2017, several rounds of talks were held in Switzerland, first in Mont-Pelerin and then in CransMontana. Nonetheless, the leaders were not able to achieve necessary further convergence on territorial adjustments, security and guarantees, ending the process fruitless one more time.

\footnotetext{
${ }^{16} \mathrm{http} / / /$ diplomaticobserver.com/_haber/the-anastasiadis-period-in-cyprus.

${ }^{17}$ https://www.bbc.com/turkce/haberler/2015/04/150426_kibris_akinci_secildi.

${ }^{18}$ Kibris Postas1 Newspaper, 8 March 2015.

${ }^{19}$ Kibris Postası Newspaper, 14 April 2015.
} 
Following another disappointing failure at peace talks, 2018 has been a year of intense political developments in the north. In January Turkish Cypriots head to the polls for parliamentary elections in the political landscape of disillusionment and fatigue with the peace process. Hence, Cyprus Problem was relatively low on the agenda of Turkish Cypriot parties' electoral campaigns. Even Cypriotist CTP and TDP refrained from instrumentalizing the EU and federal solution while highlighting economy, citizenship and asymmetric relations with Turkey. The right-wing parties' campaigns also focused on economic promises and strengthening ties with Turkey. The newly-established HP of Özersay capitalized on the widespread frustration of the disenchanted electorate with the established parties and status-quo, put the issues of corruption and malgovernance at the center of its electoral campaign and promised 'clean politics ${ }^{, 20}$.

Fading solution prospects coincided with a nationalist comeback in the elections in which the UBP returned as the largest party by gaining $35.6 \%$ of the vote and 21 seats, while the CTP had a dramatic decline in its share of vote and gained only 12 seats, revealing the importance of Cyprus problem and the EU for the party. With an unimpressive electoral campaign focusing on domestic issues, most Turkish Cypriots who swung to CTP since mid-2000s, voted for the new HP whose centrist approach and anti-status quo rhetoric appealed to many who desire change but are pessimistic about a Cyprus solution. The party's remarkable success for a new party indicates a deal fatigue concerning the Cyprus Dispute among a considerable number of Turkish Cypriots and prioritization of domestic issues. In the end, the election results disabled any party to establish a majority government. All parties which passed the 5\% threshold ruled out any coalition talks with UBP which they saw as the main architect of the status-quo. Eventually the largest party in the parliament was ousted from power with the establishment of a 4-party coalition government by the CTP, TDP, HP and DP. The growing consensus that the status-quo is breakable with domestic means brought these parties together despite their ideological divergence on the Cyprus Dispute. Particularly, DP's decision for not extending its partnership with its previous partner UBP manifested a shift in its identity from Turkish Cypriot nationalism to a light version of Cypriotism. This brought the party closer to Cypriotist parties as well as the HP which promised a more balanced relationship with Turkey. DP's resistance against religious pressure from Ankara and emphasis on secularism has been particularly important in the establishment of the coalition. ${ }^{21}$

The success of UBP in the elections and the determination of other parties to exclude the nationalist party from the coalition reveal that Turkish Cypriot identity continues to be contested between different notions. Nonetheless, inertia in peace negotiations and declining hopes for peace after Crans-Montana, shifted the source of this contestation from Cyprus Dispute towards domestic politics and relations with Turkey. Having said that, the views of Turkish Cypriot coalition government resonated with those of Akınc1, which facilitated efforts in restoring trust and a comprehensive settlement (Grigoriadis 2018). Recently, the leaders announced new confidence building measures including mobile phone network link to

\footnotetext{
${ }^{20}$ HP Election Manifesto, 2018.

${ }^{21}$ Elcil, S. 2019, Our Friends in the North, Friends of Cyprus, Issue 61.
} 
facilitate greater interaction, further demining and the exchange of works of art belonging to the respective communities. Nonetheless the future of fragile coalition government remains ambiguous considering its deep divergence with the AKP and the delays in transfer of financial support from Ankara which is viewed as an instrument of political pressure. Turkey's attempts to bypass Akıncı and negotiate directly with Greek Cypriots over alternative models of solution including a 'loose/ decentralized federation' 22 also raises prospect of tension with Ankara in the foreseeable future.

\section{Conclusion}

As a conclusion, the Turkish Cypriot identity is in the process of reconstructing itself following the events of 1974. In this process, two rival notions of identity are contesting with each other to shape the preferences of the Turkish side in Cyprus re-unification talks. Several factors especially after 1990s strengthened the Cypriotist identity favoring federalism vis-à-vis Turkish nationalism which upholds a two-state solution. First of all, Turkish migrants provided an 'internal other' to indigenous Turkish Cypriots and were perceived as a threat to their identity, values, norms and lifestyle. The focus on the 'other' is an essential part of identity construction process. However, as the Turkish Cypriot case reveals the group which will be put in the category of 'other' can change depending on the circumstances and does not always reflect ethnic or religious differences. Regardless of their ethnicity, any group can be regarded as 'other' if it is considered as a threat to the identity of the indigenous population. As the above discussion demonstrated, the split between Turkish Cypriots and Turkish migrants is not only limited to cultural differences but indeed reflects a growing class distinction in Northern Cyprus.

Another important factor which accelerated the rise of Cypriotism is the Europeanization of the Cyprus Dispute after 1990s. The approval of Cyprus' EU candidacy in 1994 made the Union's membership a strong possibility and reinforced the appeal of Cypriot identity which is now perceived as part of the greater European identity. Cypriotism was also strengthened through rising interaction of Turkish Cypriot civil society with European institutions which enabled a process of social learning and Europeanization of preferences. Finally, the re-structuring of Turkish Cypriot identity is also linked with the rising conservatism in Turkey since the end of the Cold War and especially after the beginning of AKP period in 2002. Although Cypriotist parties initially welcomed the anti-establishment and anti-status quo approach of the AKP which enabled their cooperation during the Annan Plan period, they later emerged as the strongest opponents of the party's policies on Cyprus. Indeed, some policies of the AKP were perceived as an existential threat to the secular lifestyle of many Turkish Cypriots including some who traditionally supported nationalist parties. Such policies were also used to justify the view that the only way to secure idiosyncratic

${ }^{22}$ Although the exact meaning of the term remains uncertain, the two parties have totally different interpretations on the concept of a 'loose federation'. 
Turkish Cypriot identity is the re-unification of the island. This perception boosted the popularity of Cypriotism which reached at its peak level during the Annan Plan period. Decline of ethnic nationalism alienated many Turkish Cypriots from their self-declared state and jeopardized the legitimacy of the TRNC. On the other hand, it undermined the perception of the Cyprus Problem as a 'national cause' in Turkey which enabled Ankara to pursue a relatively conciliatory approach during the Annan process without a strong reaction from the Turkish public.

Although disillusionment following the referenda and the feeling of rejection by Greek Cypriots threatened Cypriotism in the north, its strong opposition to status-quo and ethnic nationalism remained relevant and continued to grow especially among younger generations. Augmented interaction with the EU and limited rewards of the 'yes' vote also led to a gradual softening of Turkish Cypriots' relations with the international community and justified Cypriotist discourses. However, the bi-communal character of Cypriotism was undermined by consecutive failures in peace talks in the aftermath of the Annan Plan. Recent years witnessed the emergence of a 'light Turkish Cypriotism' which concentrates mostly on domestic issues and promises 'home cleaning' in the north. It also disapproves asymmetric relations with Ankara while questioning the appropriateness of a federal solution. Newly-established HP is currently championing this new identity although it's also shared by certain circles within DP and even leftist parties. On the other hand, Denktaş' ethno-nationalism is still shared by a significant number of Turkish Cypriots as revealed by the success of UBP in 2018 elections. Indeed, some circles within the party even support an increasing transfer of power to Ankara and integrating the TRNC to Turkey as an autonomous entity ${ }^{23}$.

In brief, fatigue with consecutive failures in peace negotiations in the postAnnan period and the current standstill transforms identities in Northern Cyprus once again, enabling the raise of alternatives to federalism and two-state solution. Nevertheless, such alternatives are still in their embryonic stage and are not widespread among the political elites. Collective rejection of Anastasides' recent references to a 'loose or decentralized federation' by all Turkish Cypriot political parties reveals their uneasiness to revise the traditional parameters of Cyprus peace talks. All in all, different notions of identity suggest different preferences in Cyprus peace talks. Dominant identities in the Turkish Cypriot community fluctuate depending on several domestic and external factors. Considering the continuance of uncertainty on the island, the contestations and tension over identity is likely to remain high in the politics of Northern Cyprus and shape Turkish Cypriot preferences in peace negotiations.

\footnotetext{
${ }^{23}$ In 2017 Turkish Cypriot foreign minister Tahsin Ertuğruloğlu from UBP said a 'Monacostyle' autonomy is an option for TRNC. Hürriyet Daily News, 4 October 2017.
} 


\section{References}

Andreou E (2015) Favouring a Cypriot identity but differing on what it means. Cyprus Mail. Retrieved from: www.cyprus-mail.com.

Barnett M (1996) Identity and alliances in the Middle East. In Culture of National Security, PJ Katzenstein (Ed). New York: Columbia University Press.

Bryant R (2004) Imagining the modern: cultures of nationalism in Cyprus. London: IB Tauris.

Dağı I (2005) Transformation of Islamic political identity in Turkey: rethinking the West and westernization. Turkish Studies 6(1): 21-37.

Eroğlu (2015) İki yıl içinde Kıbrıs Konusunu bir sonuca bağlamak için aday oldum. [Within two years I was a candidate to conclude the Cyprus issue]. Klbris Postast. Retrieved from: www.kibrispostasi.com.

Grigoriadis I (2018) Cyprus after elections. German Institute for International \& Secuity Affairs. Retrieved from: www.swp-berlin.org/fileadmin/contents/products.

Halkın Partisi (2017) The People's Party Manifesto. Retrieved from: www.halkinpartisi. biz/secim-manifestosu.

Hatay M (2005) Beyond numbers. An inquiry into the political integration of Turkish settlers in N. Cyprus'. International Peace Research Institute Oslo. Retrieved from: https://www.files.ethz.ch/isn/38138/2005_beyond_numbers_report.pdf.

Hatay M (2008) The problem of pigeons: orientalism, xenophobia, and a rhetoric of the 'local' in North Cyprus. The Cyprus Review 20(2): 145-72.

Hopf $\mathrm{T}$ (1998) The promise of constructivism in international relations theory. International Security 23(1): 171-200.

Kaymak E, Lacher H (2005) Transforming identities: beyond the politics of non-settlement in North Cyprus. Mediterranean Politics 10(2): 147-66.

Kıbrıs Postası (2015, April 14) Özersay: 'Halk bana sahip çıkıyor'. [Özersay: 'People take care of me']. Retrieved from: www.kibrispostasi.com. [Accessed February 2019].

Kınacioğlu M, Oktay E (2006) The domestic dynamics of Turkey's Cyprus policy: implications for Turkey's accession to the EU. Turkish Studies 7(2): 261-74.

Kolsto P (2006) The sustainability and future of unrecognized Quasi-States. Journal of Peace Research 43(6):723.

Kyris G (2012) Europeanization and the Turkish Cypriot political parties: how Europe matters. Turkish Studies 13(3): 471-487.

Lisaniler F, Rodriguez L (2002) The social and economic impact of EU membership on Northern Cyprus. In The European Union and the Cyprus Conflict, T Diez (Ed). Manchester: Manchester University Press.

Loizides N (2015) Ontological security in Cyprus. In Conflict Resolution and Ontological Security: Peace Anxieties, B Rumelili (Ed). London: Routledge.

Markides K (1977) The rise and fall of the Cyprus republic. New Haven and London: Yale University Press.

Mavratsas C (1998) Greek Cypriot economic and political culture: the effects of 1974. In Cyprus and its People, V Calotychos (Ed), 1955-1997. Colorado: Westview Press.

Mertkan H (2009) Cypriotism as an ideology in between Greek and Turkish nationalisms. Master Thesis. Athens: Kapodistiran University of Athens.

Özkırımlı U, Sofos S (2008) Tormented by history: nationalism in Greece and Turkey. New York: Columbia University Press.

Pollis A (1973) Intergroup conflict and British colonial policy: the case of Cyprus. Comparative Politics 5(4): 575-99. 
Psaltis C (2012) Culture and social representations: a continuing dialogue in search for heterogeneity in social developmental psychology. Culture \& Psychology 18(3): 375390.

Ramm C (2006) Assessing transnational re-negotiation in the Post-1974 Turkish Cypriot Community: 'Cyprus Donkeys', 'Black Beards' and the 'EU Carrot'. Southeast European and Black Sea Studies 6(4): 523-42.

Risse Kappen T (1996) Collective identity in a democratic community: the Case of NATO. In Culture of National Security, PJ Katzenstein (Ed). New York: Columbia University Press.

Rodger S (2015) Unrecognized states and the enduring power of identity. St. Anthony's International Review 10(2): 53-87.

SCORE (2014) Predicting peace: the social cohesion and reconciliation index as a tool for conflict transformation. Nicosia: UNDP-ACT. Retrieved from: https://bit.ly/2M 69bif.

Stephen M (1997) The Cyprus question. London: The British-Northern Cyprus Parliamentary Group.

University of Cyprus Centre for Field Studies (2017) The Anastasiadis period in Cyprus. Survey funded by Leventis Foundation cited in Friends of Cyprus, Issue 61. Retrieved from: www.diplomaticobserver.com.

Vural Y, Rüstemli A (2006) Identity fluctuations in the Turkish Cypriot community. Mediterranean Politics 11(3): 329-38.

Ya Tanınma Ya Özerklik (2017) Hürriyet. [Liberty]. Retrieved from: http://www.hurri yet.com.tr/dunya/ya-tanima-ya-ozerklik-40598918.

Yavrum Vatan (2003) Star. Retrieved from: www.gecmisgazete.

Y1lmaz M (2005) The Cyprus conflict and the question of identity. USAK. Yearbook of Politics \& International Relations 1: 427-446. 